\title{
Did Foreign Investors Destabilize the Korean Equity Market during the Asian Crisis?
}

\author{
GAB-JE JO ${ }^{*}$
}

This paper investigates the behavior of foreign equity investment in the Korean market over the period of 1995 through 2001. The main questions examined in this paper are: Is foreign equity investment is relatively more reversible than domestic investment in the wake of financial crisis? And do foreign equity investors tend to increase the volatility of the market more than domestic investors? The empirical results indicate that equity investment activity by foreigners was more reversible than domestic investment for the duration of financial crisis period. Furthermore, I have found evidence that foreign equity investors tend to cause higher volatility in the market than domestic investors.

Keywords: foreign investment, financial crisis, equity market, Korea

" Professor, Department of Economics, Keimyung University, 1000 Sindang-Dong, Dalseo-Gu, Daegu, 704-701, Korea; Tel: 82-53-580-5407; E-mail: gabjejo@kmu.ac.kr

The author would like to thank two anonymous referees for their helpful comments. 


\section{INTRODUCTION}

A number of studies have recently focused on the idea that international A portfolio investment has destabilized emerging financial markets, hence contributing to recent rash of financial dilemmas. International portfolio investment could contribute to increasing the volatility of emerging markets when foreign investors make investment decisions based on the objective of short-term gains by rushing into countries whose markets are booming and fleeing from countries whose markets are falling.

This is an important issue. For Korea, in particular, this was a key factor which accelerated its dramatic financial collapse and destabilization from mid-1997 through 1998, as a result of capital flight. Since Korea has embraced a more open and liberalized equity market for foreigners since recovering from the financial crisis, a serious question has been raised about the contingency where foreign investors could be a source of financial instability if they rush out of the market due to an investor loss of confidence and, its companion, risk shock. Another concern is that if foreigners increase market volatility this affects domestic investors as they tend to "lose-out" to foreign investors in a vulnerable emerging market since foreigners have more sophisticated investment technologies than domestic investors.

A recent study by Calvo and Mendoza (2000) argued that the combination of informational disadvantage and diversified international portfolios, generated incentives for rational herding and volatile equity flows by foreign investors. As a consequence, they may not provide a good indication of the risks of a future crisis, and if a crisis does hit, foreign portfolio investors may exacerbate the crisis by swiftly pulling their investments out of the region as a consequence of herding behavior. On the contrary, Choe et al. (1999) argued that there is evidence of positive feedback trading and herding in foreign equity investment in the Korean stock market, but an everyday event study showed that foreign investment didn't have a substantial impact on stock market volatility from the period of November 1996 through December 1997. Furthermore, Hamao and Mei (2001) argued that in Japan there is no evidence that equity investments by foreigners increase stock market volatility more than investment by domestic investors.

Actually, Choe et al. (1999) investigated similar topic as in this paper, but those two papers used different sample periods and methodologies. Choe et al. (1999) used everyday an event study in which they investigated intraday returns and volatility percentages around 5-minute intervals of large foreign price-setting order imbalances for each of the 414 stocks in the KSE (Korea Stock Exchange) from December 2, 1996 to December 27, 1997. However, this paper uses the econometrics approach in which the conditional variance from the autoregressive conditional heteroscedasticity (ARCH) model is used to measure volatility of daily stock market returns and then regress the daily volatility on the transactions by different investor 
groups. Two sample periods were used in this paper, namely the full sample period from January 1995 to December 2001 and the crisis period from July 1997 to December 1998.

This paper uses the inbound transactions data, foreigner investor's net purchases of domestic securities, to study the behavior of foreign equity flows and their effects on the Korean stock market and its volatility. The questions studied are: (1) whether foreign equity investments are relatively more reversible than domestic investment in the wake of a financial crisis; and (2) whether foreign equity investors tend to increase the volatility of the market more than domestic investors.

Section II describes the behaviors of equity investments by different investor groups. Section III examines the relative reversibility of foreign equity flows in the face of a financial crisis. Also, Section III investigates the effect of major investor groups on Korean stock market volatility. Section IV gives concluding remarks.

\section{INVESTMENT PATTERNS BY DIFEERENT INVESTOR GROUPS}

The data used herein is trading amounts by different types of investors in the Korean Stock Exchange from January 1995 to December 2001. The original database obtained from the Korean Stock Exchange contains the daily Won amount of purchase and sales by different types of investors. The types of investors are classified into three categories: Korean institutions, Korean individuals, and foreign investors. Korean institutions include banks, insurance companies, investment and trust companies, other financial institutions and non-financial companies. The foreigner investors group includes both foreign institutions and foreign individual investors. This quantitative data enables us to investigate the patterns of investment by different investor types.

Figure 1 and Figure 2 show the monthly amounts of purchases and sales as a percentage of total purchases, or sales, volumes from January 1995 to December 2001. According to Figure 1 and 2, we can find that during the financial crisis period of 1997-1998, the relative trading volume by Korean individuals as well as foreign investors increased, whereas the relative number of transactions by Korean institutions decreased.

One of reasons why the relative rate of transactions by foreign investors has recently increased is that, during and after the financial crisis, the Korean government deregulated foreign investment in the Korean equity market. In May 1997, the limit of foreign investment was increased from $5 \%$ to $6 \%$ of a firm's shares. That limit increased to $7 \%$ in November 1997, and increased drastically to $50 \%$ in December 1997. Also in May 1997, the foreign ownership limit for a firm's share increased from $20 \%$ to $23 \%$. It then increased to $50 \%$ in December 1997. 
Figure 1. Purchases by InVestors Types (\%): JAN. 1995-DeC. 2001

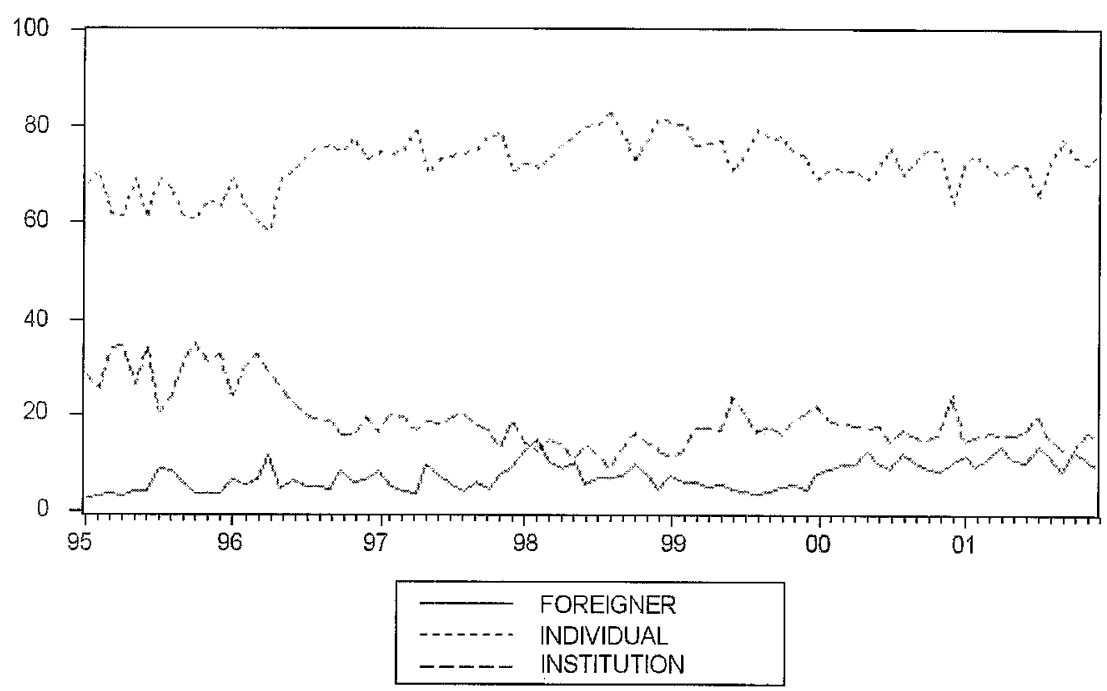

Figure 2. SAles by InVestors Types (\%): JaN. 1995-Dec. 2001

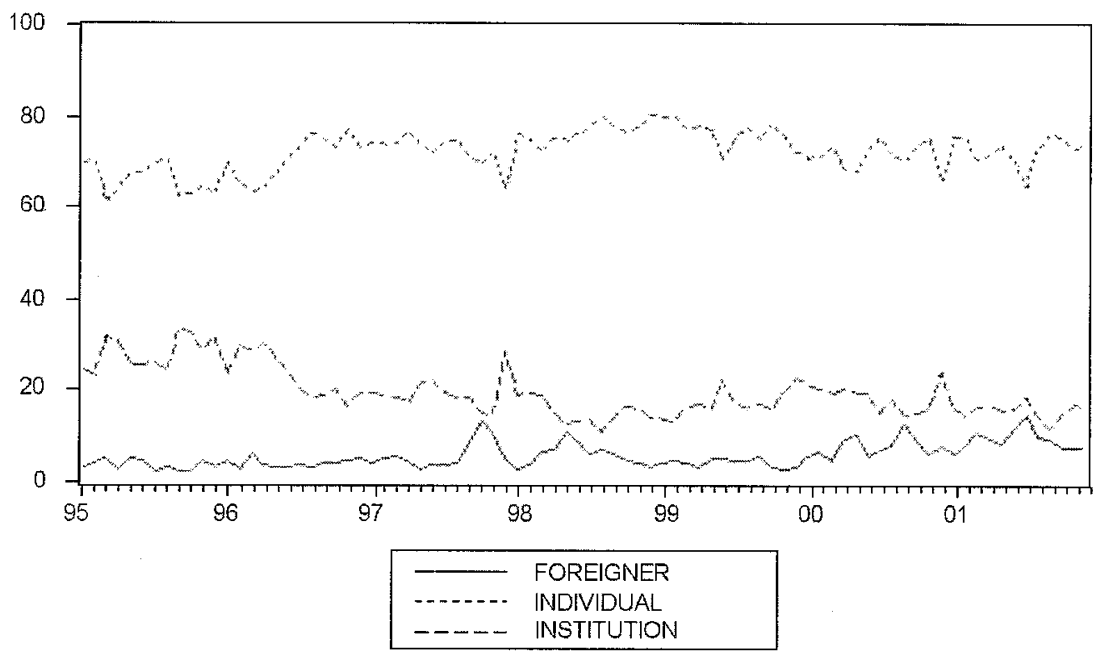

To see the flow of investment in the Korean stock market, we need to compare net purchases by different types of investors. Table 1 shows the cross correlation among net purchases by different investor types for the same period. In Table 1, we find that net investment by Korean institutions and net investment by Korean individual investors have a positive correlation, with net investments by Korean individuals lagging behind that of Korean institutions by one month. Alternatively, the correlation between net purchases by foreign investors and net investment from domestic individuals and institutions shows a substantial contempora- 
neous negative correlation. As the second part of Table 1 reports, during the Korea's financial crisis the results were similar to the results of the full sample period, but there were higher negative correlations between domestic investors and foreign investment, and a higher positive correlation between domestic individuals and institutions. The results in Table 1 enable us to find evidence that net investment by foreigners shows a substantially different pattern from that of domestic investors. It therefore appears to be meaningful to make a distinction between equity investment by foreigners and investment by domestic residents in the Korean stock market.

Table 1. Cross Correlation among Monthly Net Purchases by Investors Type

\begin{tabular}{c|c|c|c|c}
\hline & \multicolumn{2}{|c|}{ (January 1995-December 2001) } & \multicolumn{2}{c}{ (July 1997-December 1998) } \\
\cline { 2 - 5 } & Institutions & Individuals & Institutions & Individuals \\
\hline Foreign Investors & $-0.67(0)$ & $-0.66(0)$ & $-0.79(0)$ & $-0.78(0)$ \\
Institutions & & $0.24(+1)$ & & $0.47(+1)$ \\
\hline
\end{tabular}

\section{DID FOREIGN INVESTMENT DESTABILIZE THE KOREAN MARKET?}

\section{The Reversibility of Foreign Equity Investment}

Firstly, I simply measured the turnover ratio of equity investments by respective investor groups in 1997 and 1998. Table 2 shows the turnover ratios in the Korean equity market held by different types of investors. The turnover ratio in the Korean market held by respective investor groups is calculated from the ratio of annual transactions on the Korean equity market to its capitalization. According to Table 2, we find that in 1997 and 1998 domestic individuals turned over their domestic equity portfolios far faster than other investor groups did. However, it is doubtful if the turnover ratio could be good measure of relative reversibility because it is possible that the turnover ratio of the domestic individuals could be higher than those of institutes and foreigners especially during the time of crisis. A possible explanation is that during the crisis many individuals, including firm owners, whose business were bad, were sellers while others including households, whose liquidity conditions were good, were buyers. Whereas during the crisis almost all the domestic institutes were confronted with liquidity restrictions and thus it was difficult for them to be buyers.

Next, Figure 3 enables us to see that equity flows by foreign investors and equity flows by domestic investors moved in apparently opposite directions. One finding from Figure 3 is that international portfolio investors were leaders rather than followers in pulling out of the stock market. From Figure 3, we can see that foreign investors were the primary net sellers and Korean individual investors 
were the primary net buyers in the stock market at the early stage of the crisis from August 1997 to November 1997 before the IMF entered the picture with their salvation financing program. However, after the implementation of the IMF's salvation financing program in December 1997, the situation reversed itself.

Table 2. Turnover Ratios In Korean Domestic EQuities, 1997 AND 1998 (KOREAN WON TRILLIONS)

\begin{tabular}{c|c|c|c}
\hline \multicolumn{3}{c}{ A. Turnover ratios in Korean equities held by domestic institutions } \\
\hline & $\begin{array}{c}\text { Transactions in } \\
\text { domestic market }\end{array}$ & $\begin{array}{c}\text { Equity Market } \\
\text { Capitalization }\end{array}$ & Turnover Ratio \\
\hline 1997 & 62.9 & 42.6 & 1.48 \\
\hline 1998 & 58.4 & 25.3 & 2.31 \\
\hline
\end{tabular}

B. Turnover ratios in Korean equities held by domestic individuals

\begin{tabular}{c|c|c|c}
\hline & $\begin{array}{c}\text { Transactions in } \\
\text { domestic market }\end{array}$ & $\begin{array}{c}\text { Equity Market } \\
\text { Capitalization }\end{array}$ & Turnover ratio \\
\hline 1997 & 312.0 & 28.4 & 11.0 \\
\hline 1998 & 298.0 & 30.0 & 9.95 \\
\hline
\end{tabular}

C. Turnover ratios in Korean equities held by foreign investors

\begin{tabular}{c|c|c|c}
\hline & $\begin{array}{c}\text { Transactions in } \\
\text { domestic market }\end{array}$ & $\begin{array}{c}\text { Equity Market } \\
\text { Capitalization }\end{array}$ & Turnover Ratio \\
\hline 1997 & 21.7 & 12.4 & 1.75 \\
\hline 1998 & 28.8 & 17.0 & 1.69 \\
\hline
\end{tabular}

One possible explanation for this phenomenon is that international investors transmitted a sort of financial contagion from the Hong Kong stock market crash and Taiwanese devaluation in October 1997. This explanation contrasts with the Calvo-Mendoza (2000) analysis, in which they suggest that international portfolio investors would be followers rather than leaders in pulling out of the market, since foreign investors have an informational disadvantage relative to resident investors. Another finding from Figure 3 is that at the heart of the crisis from late 1997 to the early 1998 , the primary net sellers were domestic individuals and the primary net purchasers were foreign investors in the Korean equity market. This indicates that foreign equity investment was sharply reversed from primary net sellers to primary net buyers after the IMF implemented its salvation financing program. At the early stage of the crisis before the IMF implemented its salvation financing program, foreigners were primary in capital flight mode and, as stated, during and after the crisis the Korean government deregulated foreign investment in the Korean equity market in a favorable way for foreign investors and foreign equity inflows increased sharply. Considering the role of the information on risk and profit 
earning opportunity, these results show that foreign investment was more reversible during the crisis.

Figure 3. Net Purchases by Investors Types (Won): Jan. 1997-Dec. 1998

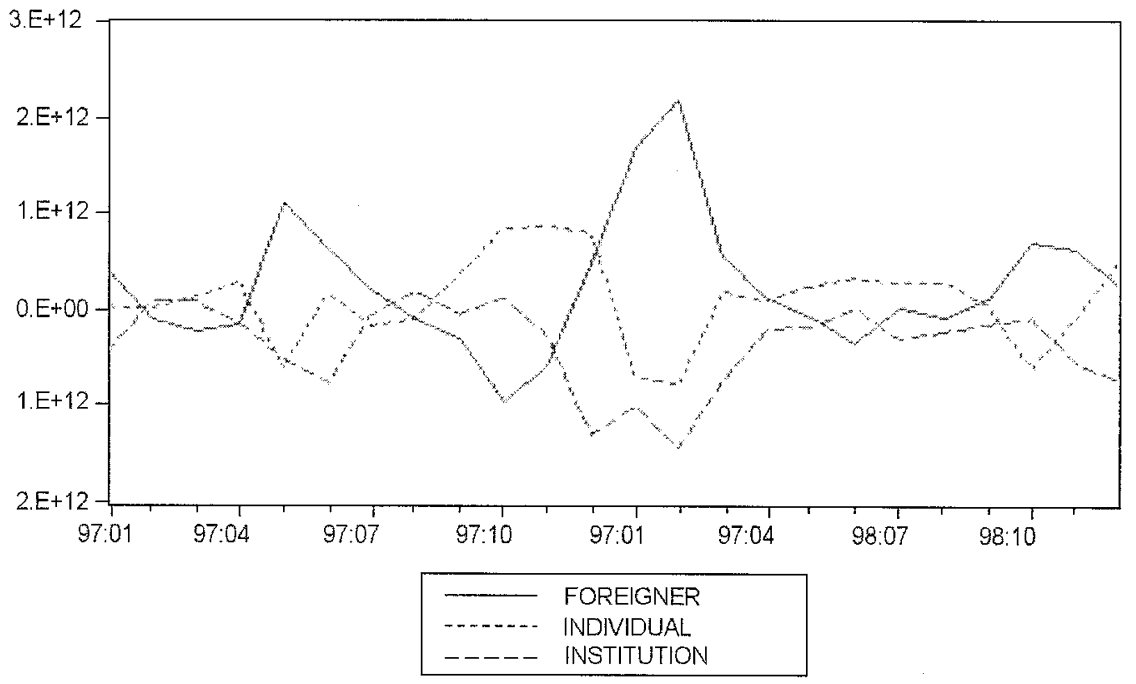

In summation, regarding whether foreign equity investment is more reversible than residential equity investment in the face of such a financial crisis, I find evidence to support that foreign investment was more reversible than domestic investment for the financial crisis period. Foreign investors were the leaders in pulling out of the market at the early stage of the crisis before the IMF's implemented its salvation financing program, whereas since December 1997, after the IMF salvation financing program, the pattern of foreign investment has reversed and they are the primary net buyers as market started to provide favorable profit making opportunities.

\section{Foreign Equity Investment's Impact on Market Volatility}

The next question to be examined in this paper is whether foreign investors tend to increase market volatility in Korea as they tend to make short-term investment decisions. As the trading volume by foreign investors has substantially increased after the financial crisis of 1997 and 1998, now the Korean government and Korean investors are more concerned about the impact of foreign investors on market volatility.

To measure volatility of daily stock market returns, I used conditional variance by using Engle's (1982) ARCH (autoregressive conditional heteroscedasticity) model. Conditional variance is the weighted average of lagged squared residuals at time $\mathrm{t}$ from an appropriate model of stock market return 


$$
\begin{aligned}
& \gamma_{t}=u+\sum_{i=1}^{p} \phi_{i} \gamma_{t-i}+\sum_{i=1}^{p} \delta_{i} \varepsilon_{t-i}+\varepsilon_{t} \\
& \varepsilon_{t} \mid\left(\varepsilon_{-1}, \varepsilon_{t-2}, \cdots \cdots\right) \sim N\left(0, \sigma_{t}^{2}\right) \\
& \sigma_{t}^{2}=\alpha_{0}+\alpha_{1} \varepsilon_{t-1}^{2}+\alpha_{2} \sigma_{t-1}^{2}
\end{aligned}
$$

where $\gamma_{t}$ is the stock market return represented as log first difference of KOSPI, $u$ is a drift term and $\varepsilon_{t}$ is the white-noise process. ARMA $(1,1)$ was chosen as the best fitting model of stock market returns. $\sigma_{t}^{2}$ the conditional variance, which is a function of $\varepsilon_{t-1}^{2}$ and $\sigma_{t-1}^{2}$. Table 3 shows the estimation results from equation (1).

TABLE 3. ESTIMATION RESULTS OF ARCH MODEL

\begin{tabular}{c|c|c}
\hline & The Mean Equation & The Variance Equation \\
\hline C & $-0.000(-0.37)$ & $0.000 * *$ (2.49) \\
& $-0.211 \quad(-1.41)$ & $0.064 * * *(7.63)$ \\
& $0.344 * *(2.37)$ & $0.937 * * *(117.99)$ \\
\hline R & \multicolumn{2}{|}{} \\
D.W & \multicolumn{2}{|c}{} \\
\hline
\end{tabular}

NOTES: $*, * *, * * *$ denote $10 \%, 5 \%, 1 \%$ significance levels respectively, and the values in parentheses are $\mathrm{Z}$ statistics.

Figure 4. KOSPI AND VOlatility OF STOCK MARKET: JAN. 1995-DeC. 2001

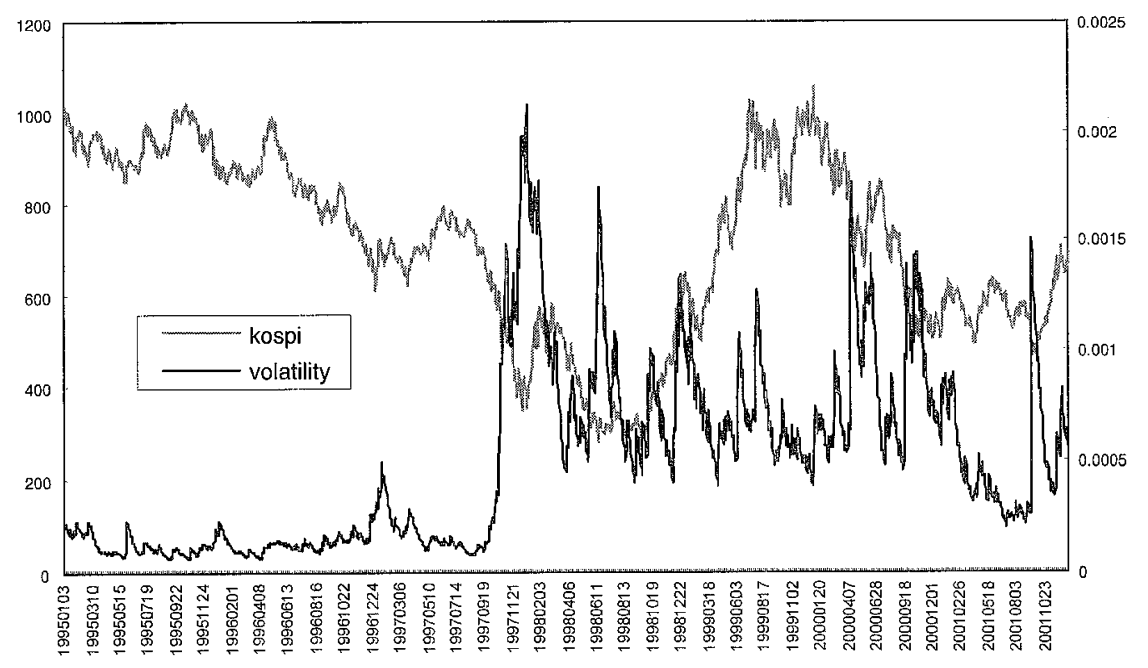

Figure 4 presents the trends of volatility of the Korean stock market and KOSPI from January 1st 1995 to December 30th 2001. According to Figure 4, we can see a substantial difference in volatility between the periods before and after the 
crisis occurred. There was relatively low market volatility before the financial crisis, and it suddenly increased when the crisis occurred. Volatility stayed relatively high for the post-crisis period.

In this section, to investigate whether trading by foreign investors caused higher market volatility I carried out the following regression:

$$
C V_{t}=C+\alpha_{0} C V_{t-1}+\alpha_{1} C F_{i t}+\varepsilon_{t}
$$

where $C V_{t}$ is the volatility at time $\mathrm{t}, C F_{t}$ is the vector of transactions by different investor types (the absolute value of net purchase amounts, i.e., the total transaction volume) and $\varepsilon_{t}$ is the error term. Since we are interested in whether increased transactions either net selling or net purchasing increase volatility, I use the absolute value of net purchase time series. The sample period I examine in this test is from January 1, 1995 to December 28, 2001, and the crisis period July 1, 1997 to December 28, 1998. Because most of the series appears to have the $I(0)$ process, I used the data in level form. I included the lagged variable of volatility to capture the persistence of the volatility. To avoid the multicollinearity problem, I regressed to separate three equations for each investor group.

Since I am concerned about the endogeneity of the equity investment variable $\left(C F_{i t}\right)$ in the equation (2), I used the TSLS (two-stage-least-squares) proposed by Davidson and Mackinnon (1989). If $C F_{i t}$ is an endogenous variable, the estimate of the equation (2) will be inconsistent because an endogenous variable is correlated with the regression error term $\left(\varepsilon_{t}\right)$. To solve the endogeneity problem in the regression equation (2), I regress the equity investment variable $\left(C F_{i t}\right)$ on all exogenous variables and instrument variables. For instrument variables I used the lagged value of the equity investment $\left(C F_{i t-1}\right)$ and KOSPI since they are correlated with equity investment $\left(C F_{i t}\right)$ but uncorrelated with the disturbances. I then regress the second stage equation (3) below, with all of the variables replaced by the fitted values from the first-stage regressions:

$$
C V_{t}=C+\beta_{1} C V_{t-1}+\beta_{2} C \hat{F}_{i t}+\varepsilon_{t}
$$

Lung-Box Q-statistics used to check residuals from equation (3) are serially uncorrelated and white noise.

Table 4 reports the regression of the daily volatility on lagged volatility and the contemporaneous absolute value of net purchases by different investor groups, using TSLS (Two Stage Least Squares). The regressions were carried out for two sample periods, namely the full sample period from January 1995 to December 2001, and the crisis period from July 1997 to December 1998. I find evidence that the market volatility was affected by foreign equity investment, while the market volatility was not significantly affected by domestic investors' transactions. As the 2nd through 4th columns of Table 4 report, for the full sample period 
Table 4. Regression of Volatility on Net Purchase by InVestors' Type

\begin{tabular}{|c|c|c|c|c|c|c|}
\hline \multirow{2}{*}{$\begin{array}{c}\text { Test } \\
\text { Statistics }\end{array}$} & \multicolumn{3}{|c|}{ January 1995 December 2001} & \multicolumn{3}{|c|}{ July 1997 December 1998} \\
\hline & \multicolumn{3}{|c|}{$C V_{t}$} & \multicolumn{3}{|c|}{$C V_{t}$} \\
\hline $\mathrm{C}$ & $\begin{array}{l}-0.989 \\
(-1.82)\end{array}$ & $\begin{array}{l}-0.202 \\
(-1.59)\end{array}$ & $\begin{array}{c}-0.394 * * * \\
(-3.49)\end{array}$ & $\begin{array}{c}-0.632 * * \\
(-2.08)\end{array}$ & $\begin{array}{c}-0.673 * \\
(-1.80)\end{array}$ & $\begin{array}{c}-0.525 * * \\
(-2.31)\end{array}$ \\
\hline$C F_{i t}$ institution & $\begin{array}{l}0.002 \\
(0.48)\end{array}$ & n.a & n.a & $\begin{array}{c}0.021^{*} \\
(1.90)\end{array}$ & n.a & n.a \\
\hline$C F_{i t}$ individual & n.a & $\begin{array}{l}0.006 \\
(1.28)\end{array}$ & n.a & n.a & $\begin{array}{c}0.023^{*} \\
(1.65)\end{array}$ & n.a \\
\hline$C F_{i t}$ foreigner & n.a & n.a & $\begin{array}{c}0.012 * * * * \\
(3.17)\end{array}$ & n.a & n.a & $\begin{array}{c}0.018^{* *} \\
(2.09)\end{array}$ \\
\hline$C V_{t-1}$ & $\begin{array}{c}0.993 * * * \\
(284.58)\end{array}$ & $\begin{array}{c}0.991 * * * \\
(272.58)\end{array}$ & $\begin{array}{c}0.985 * * * \\
(263.60)\end{array}$ & $\begin{array}{c}0.980 * * * \\
(124.36)\end{array}$ & $\begin{array}{c}0.981 * * * \\
(117.06)\end{array}$ & $\begin{array}{c}0.984 * * * \\
(160.88)\end{array}$ \\
\hline $\mathrm{R}^{2}$ & 0.989 & 0.989 & 0.989 & 0.989 & 0.989 & 0.989 \\
\hline D-W statistics & 2.02 & 2.03 & 2.05 & 2.10 & 2.12 & 2.08 \\
\hline
\end{tabular}

NOTES: the numbers in parentheses are $\mathrm{t}$ statistics and $(*, * * * * *)$ denotes $10 \%, 5 \%$, and $1 \%$ significance level respectively

Table 5. Regression of Volatility on Total Transactions by InVestors' Type

\begin{tabular}{|c|c|c|c|c|c|c|}
\hline \multirow{2}{*}{$\begin{array}{c}\text { Test } \\
\text { Statistics }\end{array}$} & \multicolumn{3}{|c|}{ January $1995 \sim$ December 2001} & \multicolumn{3}{|c|}{ July $1997 \sim$ December 1998} \\
\hline & & $C V_{t}$ & & & $C V_{t}$ & \\
\hline $\mathrm{C}$ & $\begin{array}{c}-0.199 * * * \\
(-2.62)\end{array}$ & $\begin{array}{c}-0.283 * * * \\
(-2.83)\end{array}$ & $\begin{array}{c}-4.419 * * * \\
(-4.46)\end{array}$ & $\begin{array}{l}-0.344^{*} \\
(-1.91)\end{array}$ & $\begin{array}{c}-0.566 * \\
(-1.91)\end{array}$ & $\begin{array}{c}-0.980 * * * \\
(2.65)\end{array}$ \\
\hline$C F_{i t}$ institution & $\begin{array}{c}0.005 * * \\
(2.13)\end{array}$ & n.a & n.a & $\begin{array}{l}0.011 \\
(1.63)\end{array}$ & n.a & n.a \\
\hline$C F_{i t}$ individual & n.a & $\begin{array}{c}0.007 * * \\
(2.46)\end{array}$ & n.a & n.a & $\begin{array}{c}0.018^{*} \\
(1.73)\end{array}$ & n.a \\
\hline$C F_{i t}$ foreigner & n.a & n.a & $\begin{array}{c}0.012 * * * \\
(4.09)\end{array}$ & n.a & n.a & $\begin{array}{c}0.034 * * * * \\
(2.65)\end{array}$ \\
\hline$C V_{t-1}$ & $\begin{array}{c}0.993 * * * \\
(397.14)\end{array}$ & $\begin{array}{c}0.991 * * * \\
(340.94)\end{array}$ & $\begin{array}{c}0.986 * * * * \\
(314.17)\end{array}$ & $\begin{array}{c}0.991 * * * \\
(195.46)\end{array}$ & $\begin{array}{c}0.990 * * * \\
(190.56)\end{array}$ & $\begin{array}{c}0.984 * * * \\
(167.32)\end{array}$ \\
\hline $\mathrm{R}^{2}$ & 0.989 & 0.989 & 0.989 & 0.989 & 0.989 & 0.989 \\
\hline D-W statistics & 2.02 & 2.02 & 2.02 & 2.04 & 2.03 & 2.10 \\
\hline
\end{tabular}

NOTES: the numbers in parentheses are t statistics and $(*, * *, * * *)$ denotes $10 \%, 5 \%$, and $1 \%$ significance level respectively 
foreigners' investment significantly increased market volatility, whereas domestic investors did not have a significant effect on market volatility. For the crisis period, foreign investment significantly increased market volatility at a 5\% significance level, whereas both domestic individuals' and institutions' investment weakly affected market volatility at a $10 \%$ significance level. Table 4 also indicates that market volatility has persisted since Table 4 reports that coefficients on lagged variables of market volatility are significant at a $1 \%$ level.

In addition, Table 5 reports the regression of the volatility on the total transactions, purchase volume plus sale volume, by different investor groups. According to Table 5, for the full sample period the equity the investments by all investor types significantly increased market volatility. However, for the crisis period, the market volatility was weakly or not affected by domestic investors' transactions, but the market volatility was significantly affected by foreign equity investment. Here, I do find some evidence that foreign transactions did tend to increase market volatility more than domestic transactions particularly during the financial crisis.

\section{CONCLUDING REMARKS}

This paper examines the effect of equity investment by foreign investors on Korean stock market volatility, as well as the relative reversibility of foreign equity investment during the financial crisis. The results indicate that it is meaningful to distinguish between portfolio investment by foreign investors and investment by residents. I find that foreign equity investors reversed sharply from the primary net sellers to primary net buyers after the IMF implemented its salvation financing program during the crisis. Consequently, the results support that foreign portfolio investment is more reversible than residents' investment in the wake of the financial crisis.

I also find some evidence that equity investment by foreigners tends to increase market volatility levels more than investment by residents in the Korean market particularly during the crisis. Using two stage least squares (TSLS), when I investigated the impact of the absolute value of net purchases by three investor groups (foreign investors, domestic institutions, and domestic individuals) on daily stock market volatility measured from GARCH model, foreign investment had a significant impact on market volatility. This is in contrast to domestic institutions and domestic individuals who did not have a significant effect on market volatility both from January 1995 to December 2001 and the crisis period. Furthermore, the regression of the volatility on the total transactions by different investor groups also supports the finding that foreign transactions did tend to increase market volatility more than domestic transactions particularly during the crisis.

This result from Korean market data is different from the Japanese example as analyzed in Hamao and Mei (2001) in which they argued that in Japan there 
is no evidence that equity investments by foreigners increase stock market volatility more than investment by domestic investors. This could be explained by the differences in the Korean versus the Japanese market. The results from the Korean market data might be different from Japan's example since the Korean market was an emerging market, thus, during the Asian financial crisis was more vulnerable while the Japanese market was an established and avoided the crisis. I think one topic for further related research would be a comparative analysis of the different roles and impact of foreign equity investment on market volatility in various countries, especially between emerging markets and established markets as well as between countries that have suffered crises and countries that have not suffered crises.

\section{REFERENCES}

Calvo, G., and E. G. Mendoza. 2000. Rational Contagion and the Globalization of Securities Markets. Joumal of International Economics 51(1): 79-113.

Choe, H., B. C. Kho., R. M. Stultz. 1999. Do Foreign Investors Destabilize Stock Market? The Korean Experience in 1997. Journal of Financial Economics 54(2): 227-264.

Davidson, R., and J. G. MacKinnon. 1989. Testing for Consistency using Artificial Regression. Econometric Theory 5(2): 363-384.

Engle, Robert F. 1982. Autoregressive Conditional Heteroskedasticity with Estimates of the Variance of United Kingdom Inflation. Econometrica 50(4): 987-1007. Hamao, Y., and J. Mei. 2001. Living with the "enemy": an analysis of foreign investment in the Japanese equity market. Journal of International Money and Finance 20(5): 715-735.

Jo, G. J. 2001. The Composition of International Capital Flows in Asia. Asia Pacific Journal of Economics and Business 5(2): 4-23.

Tesar, L. L., and I. M. Werner. 1995. Home bias and high turnover. Journal of International Money and Finance 14(4): 467-492. 